\title{
Impact of the use of gonadotropins on embryonic development - a rat model
}

\section{Impacto do uso de gonadotrofinas no desenvolvimento embrionário - modelo experimental rato}

\author{
Juliana Polisseni 1,2,3, João Gabriel Viana de Grázib 2, Martha de Oliveira Guerra 2, Larissa Cabral Milen 2, Luiz Sérgio de Almeida \\ Camargo ${ }^{1}$, Vera Maria Peters ${ }^{2}$
}

${ }^{1}$ Brazilian Agricultural Research Company, Dairy Cattle, Juiz de Fora, Minas Gerais, Brazil

${ }^{2}$ Centre for Biology Reproduction, Federal University of Juiz de Fora, Juiz de Fora, Minas Gerais, Brazil

${ }^{3}$ Assisted Reproduction Clinic Pró-Criar/Monte Sinai, Juiz de Fora, Minas Gerais, Brazil

\begin{abstract}
RESUMO
Objetivo: Avaliar o impacto da superovulação sobre o desenvolvimento embrionário inicial em ratos. Métodos: Experimento 1: Ratas Wistar foram superovuladas com PMSG seguido de hCG 48 horas depois. Os embriões foram coletados $24 \mathrm{~h}$ após a administração de hCG. Experimento 2: ratas Wistar $(n=16)$ foram distribuídas entre os grupos controle e superovulado. Os embriões foram coletados 48 e 72 h após a administração de hCG. O número total de estruturas embrionárias e o grau de qualidade de embriões foram analisados pelo teste de Qui-quadrado. Já a diferença dos pesos dos ovários foi avaliada pelo teste $t$ de Student. Resultados: Experimento 1: 931 embriões foram coletados de 66 animais, com média de 16,3 \pm 9,5 estruturas por animal. A superovulação foi bem sucedida em $89,4 \%$ dos animais, e $98,2 \%$ dos embriões obtidos a partir de animais superovulados foram viáveis. Experimento 2: 0 grupo superovulado apresentou ovários com maior peso, um maior número de embriões $(P<0,001)$, quando comparado com o grupo controle. No entanto, os embriões do grupo superovulado apresentaram menor número de células em 72 horas após a administração de hCG $(P<0,001)$. A maior porcentagem de embriões do grupo superovulado foi classificada como grau I ou II em relação aos embriões do grupo controle $(P<0,001$ e $P=0,008$, respectivamente). Conclusão: A superovulação foi bem sucedida no modelo rato $e$ resultou em um maior número de embriões coletados, por animal. Entretanto, embriões produzidos de ratas superovuladas apresentaram um desenvolvimento mais lento.
\end{abstract}

Palavras-chave:superovulação, o desenvolvimento do embrião, grau embrião, modelo animal

\section{ABSTRACT}

Objective: To evaluate the impact of in vivo superovulation on early embryonic development in a rat model. Methods: Experiment 1: Female Wistar rats were superovulated with injection of PMSG followed by hCG 48 hours later. Embryos were collected $24 \mathrm{~h}$ after hCG administration. Experiment 2: Female Wistar rats $(n=16)$ were distrbuted to a control or superovulated group. Embryos were collected 48 and 72 h after hCG administration. The total number of embryonic structures and the embryo quality grades were analyzed by Chi-squared test. Between-group differences in ovarian weight were assessed by Student's t-test. Results: Experiment 1: 931 embryos were collected from 66 animals, with a mean of $16.3 \pm 9.5$ structures per animal. The superovulation was successful in $89.4 \%$ of the animals, and $98.2 \%$ of the embryos collected from superovulated animals were viable. Experiment 2: The superovulated group had heavier ovaries and produced more embryos than the control group $(P<0.001)$; however, these embryos contained fewer cells than controls at 72 hours after hCG administration $(P<0.001)$. A greater percentage of embryos from the superovulated group were classified as grade I or grade II relative to embryos from the control group $(P<0.001$ and $P=0.008$, respectively). Conclusion: Superovulation was successful in the Wistar rat model and resulted in a greater number of embryos collected per animal. However, embryos produced as a result of superovulation developed more slowly than control embryos.

Keywords: superovulation, embryo development, embryo grade, animal model

\section{INTRODUCTION}

Despite recent advances, the success rates for assisted reproductive technologies (ARTs) remain low. Understanding the factors that impact the outcome of ART may help to improve success rates (Chuang et al., 2010, Santos et al., 2010, Younis et al., 2012). One of these factors may be the ovarian stimulation associated with superovulation. The specific protocols used for controlled ovarian stimulation may be an aspect of assisted reproduction therapy that influences the outcome of the treatment (Chuang et al., 2010). In mammals, the ovary contains a large number of dormant immature follicles that are activated over the animal's reproductive lifespan. Pituitary gonadotropins, ovarian steroids, and peptide hormones cooperate to ensure further growth and development of the activated follicles. A single dominant follicle eventually emerges, ovulates, and then involutes to allow the activation of the next group of follicles (Wu et al., 2007; Woodruff \& Shea, 2011). Both women and animals may receive treatment with exogenous gonadotropins to allow retrieval of multiple oocytes during a single menstrual/estrous cycle. Exogenous gonadotropin treatment usually consists of equine chorionic gonadotropin (eCG)/Pregnant Mare Gonadotropin (PMSG), which acts by inducing the growth of multiple follicles, followed by human chorionic gonadotropin (hCG), which promotes oocyte maturation and ovulation (Combelles \& Albertini, 2003; Kagabu \& Umezu, 2006).

However, there is still controversy over the effects of ovarian stimulation by gonadotropic hormones on subsequent embryonic development. Gonadotropin stimulation appears to have a direct impact on oxidative stress markers, induce the production of free radicals, and possibly decrease the conception rate (Younis et al., 2012). In addition, the optimal conditions necessary for implantation are altered following ovarian stimulation, 
possibly because of changes in the coordination of folliculogenesis and oogenesis (Combelles \& Albertini, 2003; Ziebe et al., 2004; Sotomaru et al., 2005; Ghaemi et al., 2008). Further studies are needed to clarify whether the use of gonadotropic hormones in ARTs has an effect on embryo development (Santos \& Macklon, 2010).

The success of ART depends on the quality of the embryos used for embryo transfer, and improvements in embryo quality may enhance the rates of implantation, pregnancy and live birth (Lee et al., 2012). Many parameters can be used to select embryos for transfer, but embryo morphology is the most commonly used criterion to assess embryo quality. However, since many investigators have raised doubts about the correlation between morphological features and pregnancy rates (Li et al., 2004), the degree of cellular fragmentation and the number of blastomeres per embryo are other main factors used for embryo selection. In addition, early cleavage rate may also influence the potential of the embryo to successfully implant (Lee et al., 2012).

In this study we evaluate the relationship between superovulation and embryo quality. We utilize gonadotropic hormones to cause superovulation in a rat model to examine the role of superovulation in folliculogenesis and ovulation in vivo. In addition, the effects of superovulation on the quality of early embryonic development (number of cells, speed of cleavage, grade of embryo) were assessed.

\section{MATERIAL AND METHODS}

\section{Chemicals}

All chemicals used in this study were purchased from Sigma

Chemical Co. (St. Louis, MO), unless otherwise indicated.

\section{Animals}

Twelve-week-old female Wistar rats weighing approximately $160.0 \mathrm{~g}$ and 14 week old male Wistar rats of previously proven fertility were obtained from the vivarium of the Centre for Biology Reproduction (CBR), Juiz de Fora, Brazil. The animals were housed in a climate-controlled animal research facility at a temperature of $21^{\circ} \mathrm{C}$ and with a light / dark cycle of 12 / 12 hours. Standard rat chow (Nuvilab ${ }^{\circledR}$, Paraná, Brazil) and filtered water were available ad libitum. This work was approved by the Committee of Ethics and Animal Experimentation-UFJF number 003/2009.

\section{Superovulation}

$150 \mathrm{IU} / \mathrm{kg}$ of PMSG (Pregnant Mares Gonadotropin, Sigma - Catalog 4877-G) were administered to stimulate folliculogenesis, and $48 \mathrm{~h}$ later ovulation was induced with $75 \mathrm{IU} /$ kg of hCG (Human Chorionic Gonadotropin, Sigma - Catalog G-8554) (Kon et al., 2005). Injections were intraperitoneal and control animals received injections of normal saline at equivalent time points.

Experiment 1: Is superovulation effective in stimulating folliculogenesis and in vivo ovulation?

Sixty six female Wistar rats aged 12 weeks were superovulated as described above. Immediately after hCG administration the female rats were moved into individual cages and mated with a male of proven fertility. On the following morning vaginal smears were performed. Females with signs of successful copulation (a "vaginal plug" and/or the presence of sperm in the smear) were euthanized 24 hours after hCG administration using a combination of $2 \%$ xylazine $(10 \mathrm{mg} / \mathrm{kg}$, Syntec, Cotia, SP) and $10 \%$ ketamine $(90 \mathrm{mg} / \mathrm{kg}$, Syntec, Cotia, SP). Oviducts and uterine horns were dissected and removed en bloc with the cranial vagina. They were then separated and placed in a $35 \mathrm{~mm}$ petri dish containing $1.0 \mathrm{ml}$ of TALP HEPES medium (Gordon, 1994) pre-heated to $37^{\circ} \mathrm{C}$. Embryo collection was performed separately from the oviduct and uterine horns using a $3.0 \mathrm{ml}$ syringe and 30 gauge needle with the aid of magnifying stereomicroscopy. The recovered embryonic structures were counted and examined using an inverted microscope to evaluate their viability.

Experiment 2: Does superovulation affect early embryo development?

Sixteen female Wistar rats were divided into control and superovulated groups. Superovulation, mating, euthanasia and embryo collection were performed as described above at 48 and $72 \mathrm{~h}$ after hCG administration. The ovaries were separated from the oviducts and weighed using an analytical balance. Embryos recovered from superovulated and control animals were examined using an inverted microscope. The total number of cells was counted and embryo quality was assessed according to the parameters described in the Handbook of the Latin American Network of Assisted Reproduction (Ahumada et al., 2006); these include assessment of blastomere symmetry, homogeneity and staining of the cytoplasm, and the presence of cytoplasmic fragmentation (Table 1).

Table 1. Embryo classification system.

\begin{tabular}{ll}
\hline Grade & Parameters \\
\hline I & $\begin{array}{l}\text { Embryo with blastomeres of equal size, no } \\
\text { cytoplasmic fragments and clear, homogeneous } \\
\text { cytoplasm. }\end{array}$ \\
\hline II & $\begin{array}{l}\text { Embryo with blastomeres of equal size and } \\
\text { less than } 30 \% \text { of the cells contain cytoplasmic } \\
\text { fragments. }\end{array}$ \\
\hline III & $\begin{array}{l}\text { Embryo with blastomeres of different sizes; no } \\
\text { cytoplasmic fragments. }\end{array}$ \\
\hline IV & $\begin{array}{l}\text { Embryo with blastomeres of equal or unequal size, } \\
\text { with } 30 \% \text { to } 50 \% \text { of the cells contain cytoplasmic } \\
\text { fragments. }\end{array}$ \\
\hline V & $\begin{array}{l}\text { Embryo with more than } 50 \% \text { of the cells contain } \\
\text { cytoplasmic fragments. }\end{array}$ \\
\hline
\end{tabular}

\section{Statistical analysis}

Between-group differences in the total number of embryos structures obtained, embryo quality classification, and the number of blastomeres per embryo were assessed using a Chi-squared test. Differences in ovarian weight were assessed by Student's t-test. Differences were considered statistically significant if $P<0.01$.

\section{RESULTS}

Experiment 1

Superovulation was successful in 59 of 66 animals $(89.4 \%)$. A total of 931 structures were collected from 66 animals, of these 914 (98.2\%) were viable embryos. The mean number of structures per animal was 16.3 \pm 9.5 . Experiment 2

Superovulated animals had heavier ovaries than controls $(P<0.001)$ (Figure 1$)$. This was expected since gonadotropin increases the number of ovulatory follicles, and therefore the number of embryos. The total number of embryos collected from each group at 48 and 72 hours combined was 48 from the control group versus 97 from the superovulated group) $(P<0.001)$.

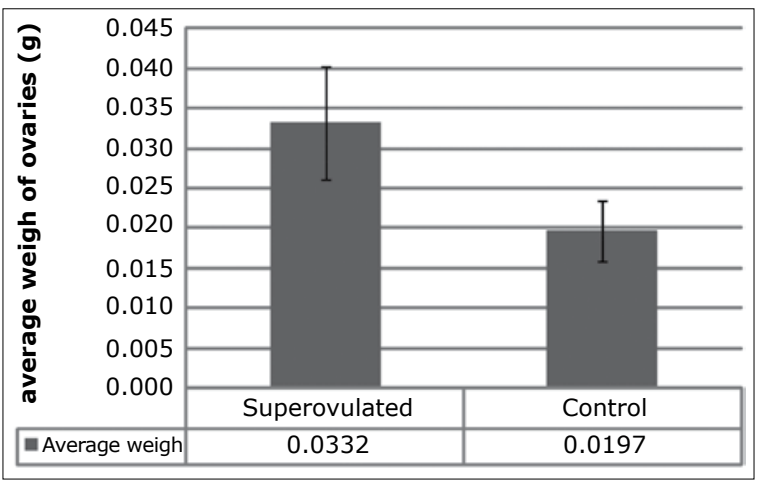

Figure 1. Average weight of ovaries in grams from the superovulated and the control group. Student's t-test showed a significant between-group difference $(P<0.001)$. 
A greater percentage of two cell embryos were collected from the superovulated group than the control group (53/97 (54.6\%) versus $16 / 48(33.3 \%)$, respectively), $(\mathrm{P}<0.001)$. This was especially evident at 72 hours after hCG administration; most (45/87) of the embryos from the superovulated rats had two cells at this time, whereas the majority of embryos from control rats had 4 cells (Table 2 ). These differences in the percentages of the embryos with different cell numbers were significant at both the $2(P<0.001)$ and $4(P=0.003)$ cell stage. Significant differences in embryo quality were seen only at 72 hours after hCG administration. At this time, a higher number of grade I and grade II structures were collected from the superovulated group than the control group $(P<0.001$ and $P=0.008$ for grade I and grade II, respectively) (Table 3 ). Since embryo quality is assessed based on blastomere symmetry and cytoplasmic fragmentation, this result may be due to the predominance of two cell embryos in the superovulated group at 72 hours after hCG administration; two cell embryos generally have good symmetry and rare fragmentation.

\section{DISCUSSION}

Controlled ovarian stimulation is frequently used with IVF to obtain multiple oocytes. Processes that occur during oocyte development within the follicle establish the foundation for embryogenesis; oocyte growth and development occur involves highly coordinated proliferation and differentiation of theca and granulosa cells. This coordination can be disrupted by exogenous gonadotropins, which may influence subsequent conception (Wu et al., 2007; Younis et al., 2012). This study demonstrates that although the technique used for superovulation was successful, initial embryonic development was significantly slower in embryos from superovulated animals. These results may indicate that, at least in Wistar rats, superovulation affects the developmental potential of the embryos obtained using this procedure. The $89.4 \%$ success rate that we obtained for our superovulation technique was similar to that reported in other studies using the same technique (Popova et al., 2005); however, individual variation in obtaining a stable number of structures was an obstacle in this study (Experiment 1 ). These difficulties are also reported in literature (Popova et al., 2002; Kito et al., 2010). It is important to emphasize that it is possible to collect as many as 33 structures from only one animal; consistent collection of large numbers of structure per animal could minimize the number of animals needed in future studies.

For this study we chose the rat as an experimental model because of their genetic similarity to humans and the frequency with which rodents are used in biomedical research. Their great availability, ease of handling, short gestation period, and metabolic homology to humans make rats a common choice as an experimental animal. Recently, it has been proposed that the rat model also be used as a tool for monitoring the quality of materials, culture conditions, techniques, and equipment used in IVF laboratories, and as a bioassay for evaluating the potential effects of environmental contaminants on fertilization and early embryogenesis (Perin et al., 2007).

Experiment 2 demonstrated that gonadotropins increase the number of ovulatory follicles, the number of oocytes and, consequently, the ovarian weight and number of embryos collected $(P<0.001)$ (Edwards et al., 2004; Kon et al., 2005; Ishigame et al., 2005; Kelley et al., 2006). The results of this study also suggest that superovulation can cause a delay in the in vivo development of Wistar rat embryos ( $\mathrm{P}=$ 0.001 ) (Table 2). Our results are similar to those of Ertzeid \& Storeng (2001), McKiernan \& Bavister (1998) and Van der Auwera \& D'Hooge (2001), who used superovulated hamsters and also observed a fewer cells in the embryos of superovulated animals. This delay in embryonic development in the superovulated group may be explained by a change in the timing of ovulation, with more ovulations occurring later in superovulated animals (McKiernan \& Bavister, 1998). In addition, the increase in the number of structures in the female reproductive tract places greater demand on the nutrients available for early embryonic development (Ghaemi et al., 2008). Importantly, the differences in embryo development between superovulated and control animals are more evident at 72 hours after hCG administration than at 48. Progression of embryonic development from the two cell stage appears to be related to the time of embryonic genome activation, which requires a suitable microenvironment to be present in both the oviduct and the uterus (Lawitts \& Biggers, 1991; Schult,

Table 2. Stage of development of embryos from superovulated and control rats at 48 and 72 hours after hCG treatment.

\begin{tabular}{|c|c|c|c|c|c|c|}
\hline \multirow[b]{2}{*}{ Treatment } & \multicolumn{3}{|c|}{ DAY $2-48 h$} & \multicolumn{3}{|c|}{ DAY $3-72 \mathrm{~h}$} \\
\hline & Superovulated & Control & $P$ value & Superovulated & Control & $P$ value \\
\hline 2 cell & $8(80.0 \%)^{(a)}$ & $15(83.3 \%)^{(a)}$ & 0.144 & $45(51.7 \%)^{(\mathrm{a})}$ & $1(5.0 \%)^{(b)}$ & $<0.001$ \\
\hline 3 cell & 0 & 0 & NS & $11(12.6 \%)^{(a)}$ & $7(35.0 \%)^{(a)}$ & 0.345 \\
\hline 4 cell & 0 (a) & $3(16.7 \%)^{(a)}$ & 0.083 & $30(34.5 \%)^{(a)}$ & $11(55.0 \%)^{(b)}$ & 0.003 \\
\hline 5 cell & 0 & 0 & NS & $1(1.2 \%)^{(a)}$ & $1(5.0 \%)^{\text {(a) }}$ & 1 \\
\hline Degenerated & $2(20.0 \%)^{(a)}$ & $8(30.8 \%)^{(a)}$ & 0.057 & 0 & 2 & 0.157 \\
\hline Total & 10 (a) & 26 (a) & 0.868 & 87 (a) & $22^{\text {(b) }}$ & 0.001 \\
\hline
\end{tabular}

Note: Between-group differences assessed by Chi-squared test. Different letters at the same stage of development indicate a statistically significant difference between treatment groups on that specific day.

Table 3. Embryo quality grades at 48 and 72 hours after hCG treatment.

\begin{tabular}{|c|c|c|c|c|c|c|}
\hline \multirow[b]{2}{*}{ Treatment } & \multicolumn{3}{|c|}{ DAY $2-48 h$} & \multicolumn{3}{|c|}{ DAY 3 - 72 h } \\
\hline & Superovulated & Control & $P$ value & Superovulated & Control & $P$ value \\
\hline Grade I & $5(50.0 \%)^{(a)}$ & $13(50.0 \%)^{(a)}$ & 0.059 & $56(64.5 \%)^{(a)}$ & $7(31.8 \%)^{(b)}$ & $<0.001$ \\
\hline Grade II & $2(20.0 \%)^{(a)}$ & 0 & 0.157 & $7(8.0 \%)^{(a)}$ & $0(0 \%)^{(b)}$ & 0.008 \\
\hline Grade III & $1(10.0 \%)^{(a)}$ & $3(11.5 \%)^{(a)}$ & 0.317 & $17(19.5 \%)^{(a)}$ & $6(27.3 \%)^{(a)}$ & 0.021 \\
\hline Grade IV & 0 & $2(7.7 \%)^{(a)}$ & 0.157 & $7(8.0 \%)^{(a)}$ & $3(13.6 \%)^{(a)}$ & 0.205 \\
\hline Grade V & 0 & 0 & NS & $0(0 \%)^{(a)}$ & $4(18.2)^{(a)}$ & 0.045 \\
\hline
\end{tabular}

Note: Between-group differences assessed by Chi-squared test. Different letters at the same grade indicate a statistically significant difference between treatment groups on that specific day $(\mathrm{P}<0.01)$. 
2002). Lee et al. (2012) demonstrated that embryos that undergo early cleavage tend to be better quality embryos. Our results demonstrate retarded development of embryos from superovulated animals, which indicates a poor prognosis for successful use in IVF. Recently, it has been hypothesized that increased rates of embryo aneuploidy may result from ovarian stimulation interfering with the natural selection of good quality oocytes, or from detrimental effects of hyperstimulation on follicle growth and oocyte maturation (Verberg et al., 2009). Assessment of embryo quality parameters revealed that more grade I and grade II embryos were obtained from superovulated animals than controls (Table 3 ). This can be explained by the developmental stage of the embryos in the superovulated group. During cell division the formation of fragments (so-called cellular debris) occurs (Moore \& Persaud 2004). As the majority of embryos in the superovulated group were still in the two cell stage 72 hours after hCG administration (Table 3 ) the likelihood of fragmentation, and also of asymmetry between the cells, was lower. This result differs from that reported by Ziebe et al. (2004), who demonstrated that embryos from superovulated humans were similar in quality to those of control subjects. Recently, investigators demonstrated an association between free fatty acids and the ovarian response to gonadotropins in women undergoing IVF, with higher fatty acids associated with poorer ovarian follicular function, poorer oocyte quality, and lower embryo implantation rates (Younis et al., 2012). In addition, Chuang et al. (2010) demonstrated that prolonged gonadotropin stimulation correlates with reduced clinical pregnancy and live birth rates after ART.

In summary, our results demonstrate that superovulation can be successful in a Wistar rat model, but that it causes slower embryonic development despite no negative impacts on embryo quality. Our data contribute to the growing consensus in the literature that suggests a detrimental impact of superovulation on the success of ART.

\section{CONFLICT OF INTERESTS}

The authors declare that they have no conflict of interest.

\section{ACKNOWLEDGMENTS}

This study was funded by the FAPEMIG - Research Support Foundation of the State of Minas Gerais, Belo Horizonte, Minas Gerais, Brazil (26/ and 31/2011). We thank João Henrique Moreira Viana for assistance in developing the work.

\section{INSTITUTION WHERE THE WORK WAS PERFORMED}

Centre for Biology Reproduction, Federal University of Juiz de Fora, Juiz de Fora, Minas Gerais, Brazil

\section{ASSISTANCE RECEIVED IN THE FORM OF FUNDING}

This study was funded by the FAPEMIG - Research Support Foundation of the State of Minas Gerais, Belo Horizonte, Minas Gerais, Brazil (26/ and 31/2011).

CONGRESS WHERE THE STUDY WAS PRESENTED: GRÁZIA, J. G. V.* ; POLISSENI, J. ; MILEN, L. C. ; SOUZA, M. L. M. ; PETERS, V. M. ; GUERRA, M. O. . Avaliação da qualidade de embriões de ratas Wistar submetidas à superovulação. In: XXXIII Semana de Biologia da UFJF, 2010, Juiz de Fora. XXXIII Semana de Biologia da UFJF, 2010. GRÁZIA, J. G. V. ; POLISSENI, J. ; MILEN, L. C. ; PETERS, V. M. ; GUERRA, M. O. . Avaliação do número e qualidade de zigotos e embriões em fases de duas a oito células de ratas wistar submetidas ao protocolo de superovulação. In: XVII Seminário de Iniciação Científica, 2011, Juiz de Fora. XVII Seminário de Iniciação Científica, 2011.

\section{Corresponding author}

Juliana Polisseni

Vicente Beguelli n 315, Dom Bosco, Juiz de Fora, Minas Gerais 36025-550, Brazil

e-mail:Jupol@powermail.com.br, Tel: +55 (32) 3216-5092, fax: +55 (32) 3232-1315

\section{REFERENCES}

Ahumada A, Olmedo SB, Liebermann J, Mauri AL, Medina R, Posada MN, Roblero L, Rosemberg E et al (2006) Procedimentos de Reprodução Assistida. In: Franco JG Jr (ed) Manual de procedimentos. Laboratório de Reprodução Assistida. REDLARA, São Paulo pp 29-48.

Chuang M, Zapatins A, Taylor M, Jindal SK, Neal-Perry GS, Lieman HJ, Polotsky AJ (2010) Prolonged gonadotropin stimulation is associated with decreased ART success. J Assist Reprod Genet 27:711-717.

Combelles CMH, Albertini DF (2003) Assessment of oocyte quality following repeated gonadotropin stimulation in the mouse. Biol Reprod 21:812-821.

Edwards LJ, Kind KL, Armstrong DT, Thompson JG (2004) Effects of recombinant human follicle-stimulating hormone on embryo development in mice. Am J Physiol Endocrinol Metab 228: 45-51.

Ertzeid G, Storeng R (2001) The impact of ovarian stimulation on implantation and fetal development in mice. Hum Reprod $16: 221-225$.

Ghaemi SR, Salahnia M, Valojerdi MR (2008) The effect of progesterone and exogenous gonadotropin on preimplantation mouse embryo development and implantation. Exp Anim 57:27-34.

Gordon I. (1994) Laboratory production of cattle embryos. CAB International, Wallingford.

Ishigame H, Medan MS, Kawaguchi M, Fukuda A, Watanabe G, Arai KY, Taya K (2005) Induction of superovulation by immunoneutralization of endogenous inhibin in immature rats. J Reprod Develop 51:559-566.

Kagabu S, Umezu M (2006) Variation with age in the numbers of ovulated ova and follicles of Wistar-Imamichi adult rats superovulated with eCG-hCG. Exp Anim 55:45-48.

Kelley RL, Kind $\mathrm{KL}$, Lane M, Robker RL, Thompson JG, Edwards LJ (2006) Recombinant human follicle-stimulating hormone alters maternal ovarian hormone concentrations and the uterus and perturbs fetal development in mice. Am J Endocrinol Metab 29:761-770.

Kito S, Yano H, Ohta Y, Tsukamoto S (2010) Superovulatory response, oocyte spontaneous activation, and embryo development in WMN/Nrs inbred rats. Exp Anim 59:35-45.

Kon H, Tohei A, Hokao R, Shinoda M (2005) Estrous cycle stage-independent treatment of PMSG and hCG can induce superovulation in adult Wistar-Imamichi rats. Exp Anim 54:185-187

Lawitts JA, Biggers JD (1991). Overcoming the 2-cell block by modifying standard components in a mouse embryo culture medium. Biol Reprod 45:245-251.

Lee MJ, Lee RK, Lin MH, Hwu YM (2012). Cleavage speed and implantation potential of early-cleavage embryos in IVF or ICSI cycles. J Assist Reprod Genet 29:745-750.

Li W, Daya S, Gunby J (2004) Faster embryo growth rate in vitro increases probability of pregnancy in assisted reproduction cycles. J Assist Reprod Genet 1271:143-146.

Mckiernan SH, Bavister BD (1998) Gonadotrophin stimulation of donor females decreases post-implantation viability of cultured one-cell hamster embryos. Human Reprod 13:724-729.

Moore KL, Persaud TVN (2004) Primeira semana do desenvolvimento humano. Embriologia básica, Elsevier, Rio de Janeiro.

Perin PM, Maluf M, Foltran DAN, Januario B, Saldiva PHN (2008) Comparison of the efficacy of two commercially available media for culturing one-cell embryos in the in vitro fertilization mouse model. Fertil Steril 90:1503-1510.

Popova E, Krivokharchenko A, Ganten D, Bader M (2002) Comparison between PMSG- and FSH-induced superovulation for the generation of transgenic rats. Molec Reprod Develop 63:177-182.

Popova E, Bader M, Krivokharchenko A (2005) Strain differences in superovulatory response, embryo development and efficiency of transgenic rat production. Transgenic Research 14:729-738.

Santos MA, Kuijk EW, Macklon NS (2010) The impact of ovarian stimulation for IVF on the developing embryo. Reprod 139:23-34. Schultz, RM (2002) The molecular foundations of the maternal to zygotic transition in the preimplantation embryo. Human Reprod Update 8:323-331. 
Sotomaru Y, Kamisako T, Hioki K (2005) Estrous stage- and animal age-independent superovulation in the BrlHan:WIST@ Jcl (GALAS) Rat. Exp Anim 54:137-141.

Van der Auwera I, D'hooghe T (2001) Superovulation of female mice delays embryonic and fetal development. Hum Reprod 16:1237-1243.

Verberg MF, Macklon NS, Nargund G, Frydman R, Devroey $P_{\text {, }}$ Broekmans FJ, Fauser BC (2009) Mild ovarian stimulation for IVF. Hum Reprod Update 15:13-29.

Woodruff TK, Shea LD (2011) A new hypothesis regarding ovarian follicle development: ovarian rigidity as a regulator of selection and health. J Assist Reprod Genet 28:3-6.
Wu J, Xu B, Wang W (2007) Effects of luteinizing hormone and follicle stimulating hormone on the developmental competence of porcine preantral follicle oocytes grown in vitro. J Assist Reprod Genet 24:419-424.

Ziebe S, Bangsboll S, Schmidt KLT, Loft A, Lindhard A, Nyboe A (2004) Embryo quality in natural versus stimulated IVF cycles. Hum Reprod 19:1457-1460.

Younis A, Clower C, Nelsen D, Butler W, Carvalho A, Hok E, Garelnabi M (2012) The relationship between pregnancy and oxidative stress markers on patients undergoing ovarian stimulations. J Assist Reprod Genet 29:1083-1089. 